\title{
16. STRATIGRAPHIC-SEISMIC SECTION CORRELATIONS AND IMPLICATIONS TO BENGAL FAN HISTORY
}

\author{
David G. Moore, Naval Undersea Research and Development Center \\ Joseph R. Curray, Russel W. Raitt, and Frans J. Emmel, Scripps Institution \\ of Oceanography, La Jolla, California
}

\begin{abstract}
Two drilling sites were proposed in the Bay of Bengal (Sites 217 and 218) in areas of anomalously thin section as determined by earlier seismic work. Although possibilities for characterizing the sediments in the normal thick section of the Bengal Fan were precluded, these holes were, nevertheless, successful in determining the ages of two unconformity-refracting horizons which had been traced throughout the entire bay. These horizons, which subdivide the sedimentary section into three units, probably mark times of both plate-edge and mid-plate deformation.

The oldest sediments in the Bay of Bengal were deposited on new sea floor formed after rifting of India from Antarctica and Australia, probably as a Cretaceous and Paleocene passive continental rise up to $12 \mathrm{~km}$ thick. First collision of India with the subduction zone lying off the southern margin of Asia occurred at the end of the Paleocene, causing both uplift of ancestral mountains in the eastern Himalayan region and deformation and unconformity across the bay. The first phase of Bengal Fan deposition was from middle Eocene into uppermost Miocene. At this time important further tectonism occurred, causing uplift of the modern Himalayas, deformation of the sea floor, and changes in sedimentation in the bay. Subsequent deposits of the modern Bengal Fan are largely undeformed.
\end{abstract}

\section{INTRODUCTION}

The international Indian Ocean expeditions of 1960 to 1965 resulted in a collection of many thousands of kilometers of bathymetric profiles by ships of several nations. These and earlier data were utilized by Heezen and Tharp (1965) to construct a physiographic chart of the Indian Ocean. Within the Bay of Bengal, their chart depicted a large submarine fan, veined with many turbidity current distributary channels, spreading out from the Swatch of No Ground submarine canyon at the northern end of the bay. In 1968, on Leg III of the CIRCE expedition of Scripps Institution of Oceanography, we conducted geological and geophysical investigations of the fan with the objective of determining sediment thickness and internal structure for studies of fan growth processes. These studies showed that the fan was both much more widespread, thicker, and structurally more complex than had been suspected previously. Well over $3 \mathrm{~km}$ of sediment were measured over most of the fan, and only near the margins of the fan over isolated basement highs and near the distal end of the fan could the base of the sediments be observed.

Seismic reflection records showed that in the distal parts of the fan on isolated structural highs and on the flanks of the Ninetyeast Ridge, the youngest fan deposits lapped unconformably on apparently older deformed fan and pelagic deposits, and these in turn unconformably overlay still older deposits of unknown origin. By tracing reflections from the first continuous strata, beneath the onlapping beds, off of the structural high and into the body of the fan, we were able to extrapolate these layers as time stratigraphic markers throughout much of the fan (Curray and Moore, 1971). These extrapolations allowed us to grossly subdivide the entire fan into three major stratigraphic units, which we believed to be younger and older fan sections and an underlying sedimentary section of unknown origin. We estimated that the sedimentary section might be as thick as $12 \mathrm{~km}$ at the northern end of the bay.

A second expedition, Leg XI of ANTIPODE in 1971, collected additional bathymetry, seismic reflection, as well as much-needed seismic refraction data with which to better define details of fan morphology (Figure 1), to determine the fan thickness and to test our earlier hypothesis. The combined data of these two cruises (Figure 2) allowed us to confirm and extend our bathymetric control and correlations of the unconformities in the fan section throughout the Bay of Bengal. Refraction and wide-angle reflection data from the second expedition indicated that within the boundaries of our projected stratigraphic units, pronounced and persistent velocity contrasts were present. The seismic refraction data also 


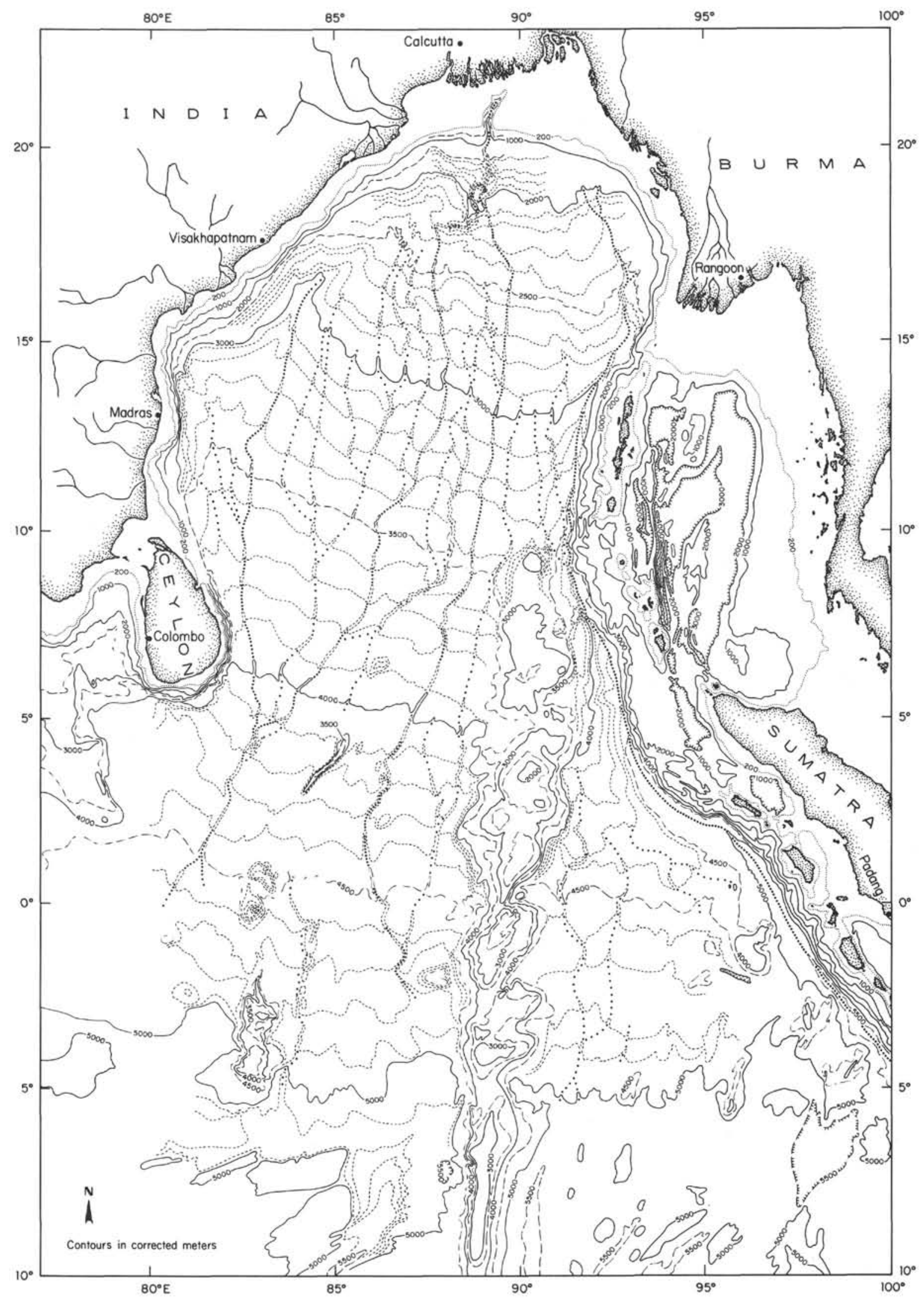

Figure 1. Bathymetric chart of the Bay of Bengal based on all available soundings. Contours by F. J. Emmel. Southern portions of the chart adapted from R. L. Fisher, unpublished charts; Andaman Sea from Rodolfo (1969). 
CORRELATIONS AND IMPLICATIONS TO BENGAL FAN HISTORY

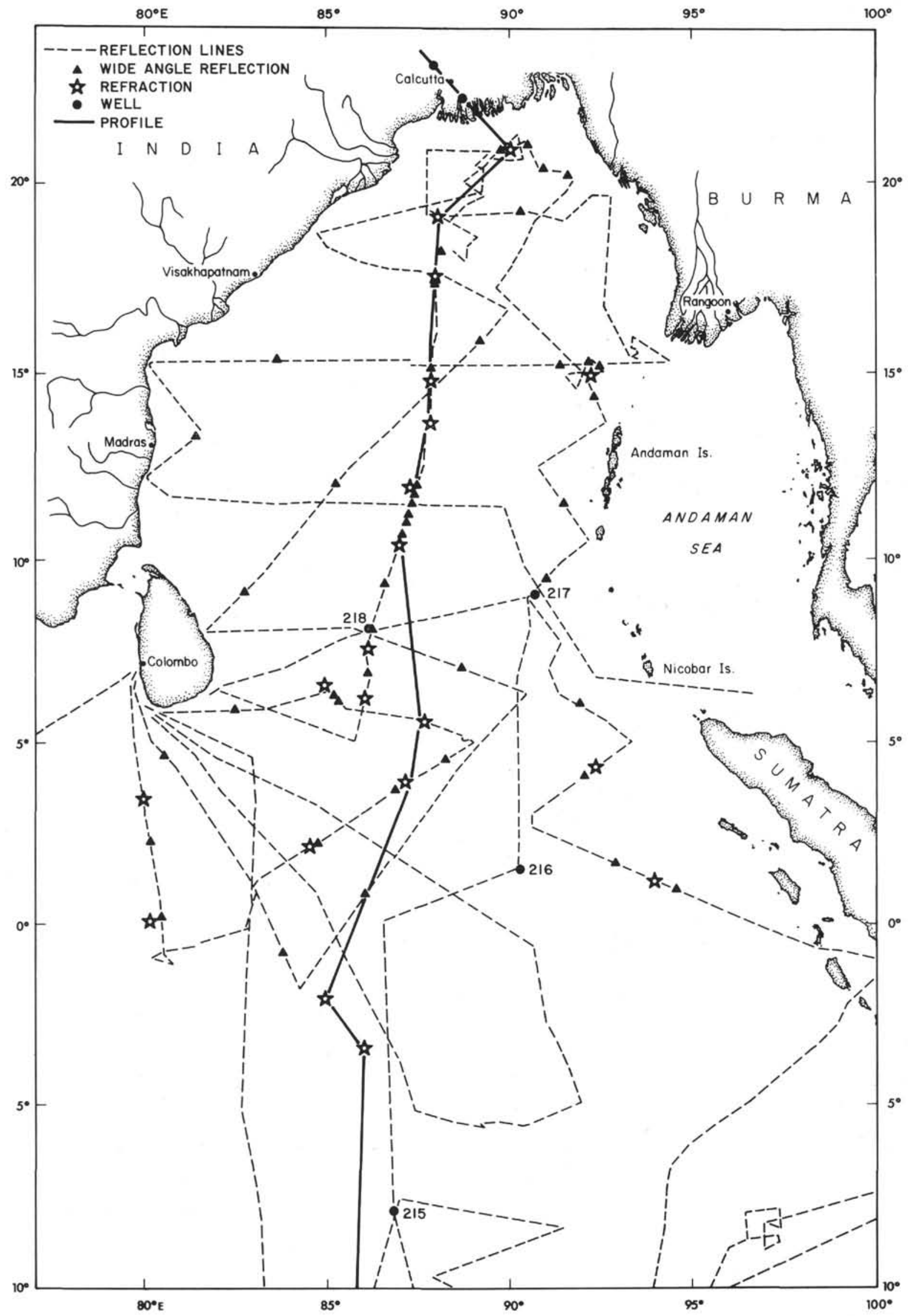

Figure 2. Tracks of parts of CIRCE and ANTIPODE expeditions and geophysical control in the Bay of Bengal.

405 
showed that the suspected great thickness of the fan was indeed real in the northern part of the bay, where over 16 $\mathrm{km}$ of sediment and material having velocities comparable to indurated sedimentary rock were measured over oceanic basement (Moore et al., 1971).

Analysis of the geophysical data from both of these cruises indicated that the uppermost velocity unit of the three sections comprising the Bengal Geosyncline was composed of turbidites with seismic velocities of 1.6 to 2.3 $\mathrm{km} / \mathrm{sec}$. Above the upper unconformity, these are generally undeformed, and this section is distinctive for the size and complexity of turbidity current fan valleys in the northern part of the fan. The volume of the total upper unit was measured to be in excess of $3 \times 10^{6} \mathrm{~km}^{3}$. The second oldest of the velocity-stratigraphic units has velocities of 2.4 to $3.3 \mathrm{~km} / \mathrm{sec}$ and appears also to consist in part of turbidites, as evidenced by buried channel and natural levee deposits which are now commonly deformed. Its volume of approximately $7 \times 10^{6} \mathrm{~km}^{3}$, coupled with the large volume of the overlying turbidites of the modern fan, suggest that this had been a region of active turbidity current deposition for long periods of time. The lowermost velocity unit, below the lower unconformity, has velocities of 4 to 5 $\mathrm{km} / \mathrm{sec}$ and overlies oceanic basement with velocities of 6 to $6.8 \mathrm{~km} / \mathrm{sec}$. The great thickness of this unit, in excess of $12 \mathrm{~km}$ under the shelf off the Ganges-Brahmaputra Delta, indicates that this region has been actively subsiding as a depositional area of geosynclinal proportions, probably since the late Mesozoic, a fact not previously considered in plate reconstructions and in evaluations of the geological history of the ancestral Himalayas.

It was with this background that we proposed two drilling sites in and adjacent to the Bengal Fan in the northeastern Indian Ocean. The specific objectives in the drilling were to: (1) determine biostratigraphic ages of the two major unconformities, (2) obtain core material of the three stratigraphic units with which to determine the prefan or older and younger fan origin of the deposits and with which to detect changes in provenance of the detrital sediments, and (3) obtain samples for paleontologic and stratigraphic control at this latitude in the northeastern Indian Ocean.

The two sites selected for the drilling were, from the beginning, at best a poor compromise. Because of the very great thickness of the most recent section of turbidites in the fan, it was necessary to select a locality at nearly the distal end of the fan in order to assure that the drill could penetrate into and below the first of the projected unconformities. Thus, the sections penetrated would probably be atypical of the lithology of most of the fan to the north and probably would contain a greater percentage of pelagic sediments. Even more difficult was the selection of a site at which the drill could penetrate the second deeper unconformity and core into the oldest sedimentary rock recorded by the geophysical work. Only on the structural high of the Ninetyeast Ridge was it possible that drilling might penetrate to the older sedimentary rocks. Beneath most of the fan, even in its distal ends near the latitude of Ceylon (Sri Lanka), the older sedimentary rocks lay at burial depths beyond drilling capability. In spite of the probable atypical nature of the sections which might be penetrated, it was hoped that information from the two proposed sites would permit us to relate Himalayan orogeny, plate motions, the closing of the Tethyan Sea, and the history of deposition of the Bengal Fan and Bengal Geosyncline.

\section{CORRELATION OF STRATIGRAPHIC AND SEISMIC SECTIONS}

\section{Upper Unconformity}

The upper unconformity recognized by Curray and Moore (1971) is traceable to the vicinity of Site 218 on reflection profiles (CIRCE Leg III, 1968) from a prominent structural high located $150 \mathrm{~km}$ to the south (Figure 3). The unconformity on the structural high is defined by turbidites onlapping folded, uplifted older turbidites and can be extrapolated into the fan section by tracing the first continuous strata reflected from beneath the onlapping beds. This, then, represents the time of inception of uplift or deformation of the hill, a process which continued through some period of time. Thus the hill is a growth structure. At Site 218 (Figure 4), the stratigraphic equivalents of these uplifted beds occur at a depth of $0.45 \mathrm{sec}$ beneath the sediment surface on the reflection records. A sonobuoy wide-angle reflection-velocity record (Ant 1115 from ANTIPODE Leg XI, 1971) in the near vicinity of Site 218 (Figure 2) gives a mean velocity of $1.60 \mathrm{~km} / \mathrm{sec}$ for the upper 480 meters. Using this velocity, the top of the stratigraphic equivalents to the uplifted beds causing the unconformity are at a depth of 360 meters in the section. Thus the unconformity is biostratigraphically uppermost Miocene in age (Site Report, Chapter 9) and coincides very closely in the section with the beginning of a lithologic zone of coarser, more sandy turbidites (pulse 2 of Thompson, Chapter 38) which extend 125 meters upsection into the late Pliocene.

In an earlier paper (Curray and Moore, 1971), we correlated the upper unconformity of the structural high on the central fan with a similar appearing onlap of folded turbidites at the flank of the Ninetyeast Ridge (Figure 5). On this basis, we incorrectly interpreted the slightly deformed turbidites below the unconformity to extend over the ridge as folded, faulted, and uplifted turbidites interbedded with pelagic sediments. The drilling at Site 217 , however, now clearly shows the entire section above the lower unconformity to be of pelagic origin (Site Report, Chapter 8). The upper unconformity cannot, therefore, be traced through the facies change barrier onto the Ninetyeast Ridge (Figure 6). On the basis of biostratigraphic age, however, the much more slowly deposited pelagic sediments, equivalent in age to the upper unconformity, were sampled at a depth of about 80 meters at Site 217 (Figure 7). This 80-meter level (uppermost Miocene) falls in the middle of the upper lithologic unit of Site 217, clay-rich nanno ooze. We would not necessarily expect lithologic changes in pelagic sediments on the Ninetyeast Ridge to coincide with the beginning of deformational stages and lithologic change in turbidites of the fan. 


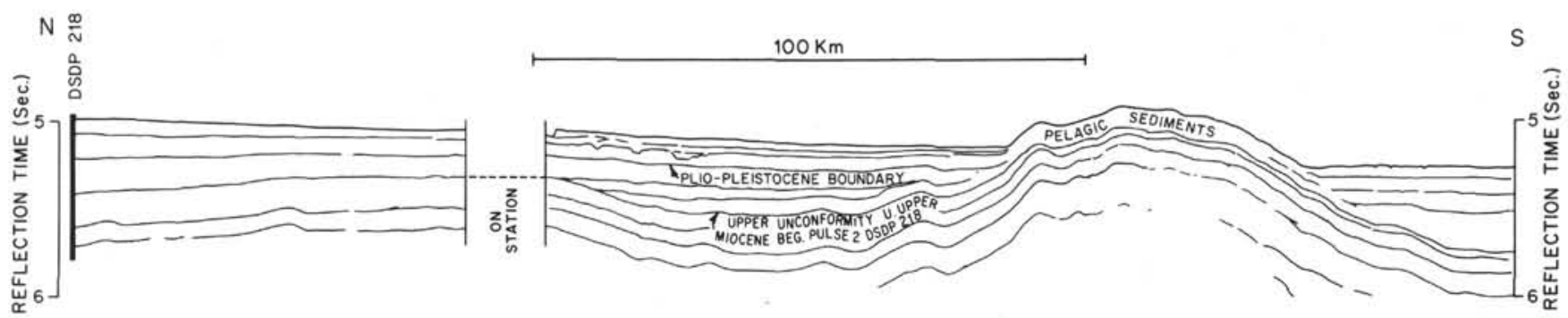

Figure 3. Line drawing of ANTIPODE expedition seismic reflection section from vicinity of DSDP Site 218 south to the crossing with the east-west line at $5^{\circ} 50^{\prime} \mathrm{N}$.

\section{Lower Unconformity}

The lower unconformity of Curray and Moore (1971) is not clearly recorded in the reflection records crossing over or near Site 218 and in any case would be much too deep to be reached by the drill. It is best recorded on reflection records on the flanks of and over the Ninetyeast Ridge, where it is also shallow enough to be sampled. At Site 217 on the northern end of the topographically expressed Ninetyeast Ridge, a reflector which can be extrapolated to the lower unconformity beneath the turbidite section appears at a reflection time of $0.41 \mathrm{sec}$ (Figures 5 and 7). Using a composite of velocities measured in the laboratory from samples recovered from Site 217 (A. C. Pimm, personal communication), a mean velocity of $1.8 \mathrm{~km} / \mathrm{sec}$ to the reflector is most plausible. This would agree with a mean interval velocity of $1.6 \mathrm{~km} / \mathrm{sec}$ for the upper lithologic unit and $1.9 \mathrm{~km} / \mathrm{sec}$ for the second lithologic unit and results in the reflector equivalent to the unconformity being at a depth of 370 meters in the Site 217 section. This depth coincides with an apparent hiatus between Paleocene and middle Eocene. It also coincides with a lithologic change, the first occurrence of cherts in the section.

Laboratory velocity measurements on other samples below this unconformity in cores from Site 217 give an approximate mean velocity of $2.5 \mathrm{~km} / \mathrm{sec}$ down to a depth of 600 meters. At this mean velocity, reflection time at 600 meters would correspond to the reflector in the reflection profiles of $0.6 \mathrm{sec}$ and would indicate that this deeper reflector is the top of the dolarenite, chert, and silicified chalk lithologic unit. An alternative explanation could result if the assumed mean velocity of $2.5 \mathrm{~km} / \mathrm{sec}$ is too low for that lithologic unit. If this is the case, the 600-meter lithologic change would occur at less than 0.6-sec reflection time, and the 0.6-sec reflection time could then correspond to basaltic basement. No wide-angle reflection stations or refraction measurements have yet been made over this part of the Ninetyeast Ridge.

\section{Correlation of Unconformities with Seismic Refraction Measurements}

At the time Curray and Moore wrote their 1971 paper, no refraction measurements had been reported in the Bay of Bengal. In 1971, on Leg XI of ANTIPODE Expedition, in collaboration with Russell W. Raitt, the seismic refraction stations shown in Figure 2 were completed. A three-fold sediment section subdivision similar to that previously based on unconformities was borne out by the refraction measurements. These are indicated in the composite longitudinal section of the Bay of Bengal shown in Figure 8, extending from the distal end of the fan at about $10^{\circ} \mathrm{S}$ through two refraction stations (published by Gaskell et al., 1959), through our own refraction, wide-angle reflection, and normal reflection measurements in the bay, to published seismic and well data in the Bengal Basin on land at the northern end (Sengupta, 1966). Careful study of our seismic reflection profiles has demonstrated that the two unconformities generally coincide with the refraction horizons between the three sediment units. The upper unit, therefore, with velocities of 1.6 to $2.3 \mathrm{~km} / \mathrm{sec}$, is uppermost Miocene to Holocene; the middle unit, with velocities of 2.4 to $3.3 \mathrm{~km} / \mathrm{sec}$, is middle Eocene to upper Miocene; and the lower unit, with velocities of 4 to $5 \mathrm{~km} / \mathrm{sec}$ is pre-upper Paleocene.

\section{DISCUSSION}

\section{Geological History}

Correlation of stratigraphic information from DSDP Leg 22 into our seismic section enables us to add the time factor to our interpretations of the geological history of the Bengal Fan and to the surrounding region. It is quite possible, in fact, that with proper interpretation, the excellent stratigraphic control from this drilling may enable higher resolution of the timing of some events in the drainage basin than through past geological work on land. The geology of the drainage and source areas in the Himalayas is, for the most part, known only through rather sparse reconnaissance work.

Our interpretation of the geological history of this region, from the breakup of Gondwanaland to the collision between India and Asia (Curray et al., in press), differs in some significant details from that of Sclater and Fisher (in press). It is reviewed briefly here without dwelling on those differences.

The position of India in Gondwanaland is controversial. We follow the reconstruction of Du Toit (1937), Carey (1958), Smith and Hallam (1970), and others in placing India nestled around Enderby Land, Antarctica. We answer the objections of Veevers et al. (1971) that western Australia was bordered by continent until breakup by considering the outline of India with an area greater than present by the amount of continental crust we presume has underthrust Tibet, much as Carey did. Breakup and separation of India from Antarctica and Australia, which were still attached together, occurred in Early Cretaceous or possibly in Latest Jurassic. We envision a relative northwest-southeast separation, about normal to the trend of the continental margin of India between Visakhapatnam and Calcutta and normal to the trends of the en echelon hills of the northern part of the Ninetyeast Ridge from $10^{\circ} \mathrm{N}$ to $6^{\circ} \mathrm{S}$ (Figure 1). This en echelon topography was first recognized by R. L. Fisher (1966, unpublished chart). This separation was perhaps caused initially by a mantle plume under the bight in the Indian continental margin southwest of Visakhapatnam and adjacent to the similar 


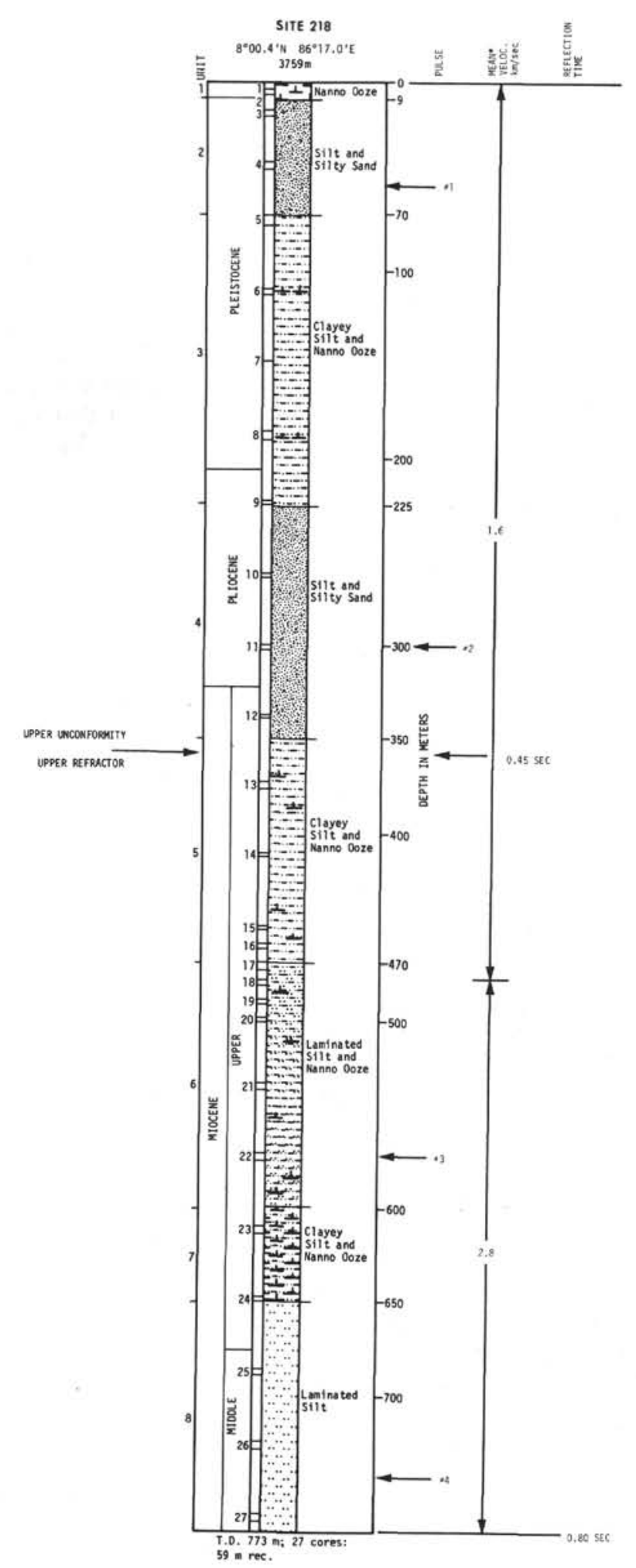

Figure 4. Stratigraphic log of Site 218 (Site Report, Chapter 9) with turbidity current pulses (Thompson, Chapter 38) and correlations with seismic data from the Bay of Bengal.

bend in the Antarctic continental margin at Cape Ann, Enderby Land. In Late Cretaceous time, relative motion changed to north-south, parallel to a transform fault located on the eastern margin of the Ninetyeast Ridge. The plate moved relatively northward over the plume, creating the age sequence of the northern Ninetyeast Ridge, from old at the north to younger at the south. Hills of the northern ridge were built above sea level and subsided after passage of the plume to the south. This change in elevation is supported by the apparent shallow water facies at Sites 214, 216 , and 217.

We believe that first collision between India, with its greater area in the north, and the subduction zone lying off the southern margin of Asia occurred in the late Paleocene. This time, obtained by backward extrapolation of presumed plate motions, appears to be consistent both with sea-floor magnetic anomalies (McKenzie and Sclater, 1971; Sclater and Fisher, in press) and with the published geology of the Himalayas. As previously mentioned, our lower unconformity, which in turn correlates with a refraction horizon which we trace throughout the bay is apparently of late Paleocene and early Eocene age and correlates with this time of collision.

The present rates and direction of convergence of India and Asia were established in early Oligocene. Sea-floor magnetic anomalies (McKenzie and Sclater, 1971; Sclater and Fisher, in press) suggest uniform convergence since then. In contrast, both the geology on land and stratigraphy of the Bay of Bengal would suggest some variation in rate and/or direction. Gansser $(1964 ; 1966)$ suggests that the major periods of late Tertiary orogeny in the Himalayas were middle Miocene and Plio-Pleistocene. Brunnschweiler (1966) suggests orogeny concentrated in the Oligocene in the Indo-Burman Ranges, and Karunakaran et al. (1964) believe the Andaman and Nicobar islands were uplifted in middle and late Miocene.

Establishment of the present plate motion in early Oligocene may correlate with the hiatus observed at that age in many sites, including Site 217 , and presumably associated with major changes in ocean circulation. We have not recognized either a traceable unconformity or refraction horizon in our seismic records of the Bengal Fan at that time. Middle Miocene, Gansser's $(1964 ; 1966)$ presumed time of first major uplift of the Himalayas, does not appear as a significant time in either of the two sites. Perhaps the time of our upper unconformity and refraction horizon, uppermost Miocene, more accurately defines that time of Himalayan orogeny rather than middle Miocene. These are all questions to which no definite answers can yet be given. The geological history of the source areas of the Bengal Fan and the adjacent plate-edge mountains (Himalayas, Indo-Burman Ranges, Andaman and Nicobar islands, and Barisan Mountains of Sumatra) should be reexamined in light of these drilling results.

\section{Relationship Between Tectonics and Sedimentation}

The unconformities which can be traced through the geophysical section of the Bengal Fan must imply mid-plate tectonic deformation. As we have defined each of our unconformities, they mark the time of inception of uplift of a hill or relative uplift on the flanks of the Ninetyeast Ridge (Figures 3 and 5). Many of these hills are obviously growth structures, with deformation continuing through some period of time. We do not know the cause of the 


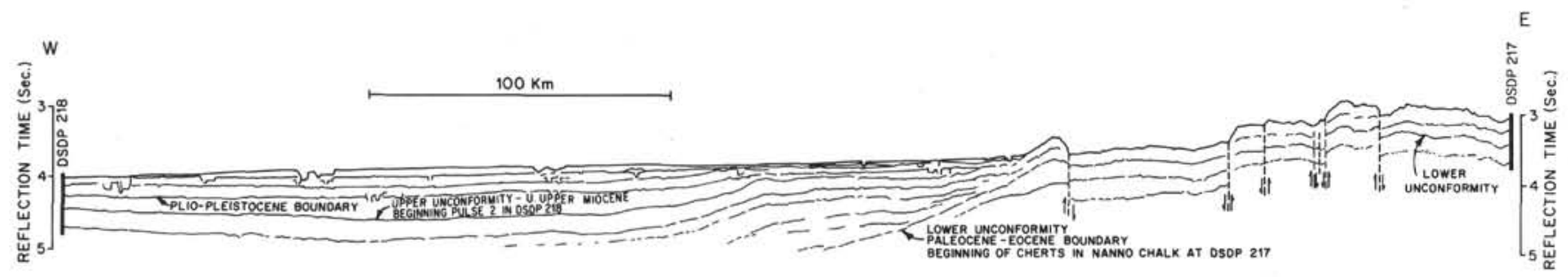

Figure 5. Line drawing of Glomar Challenger seismic reflection section between Sites 217 and 218.

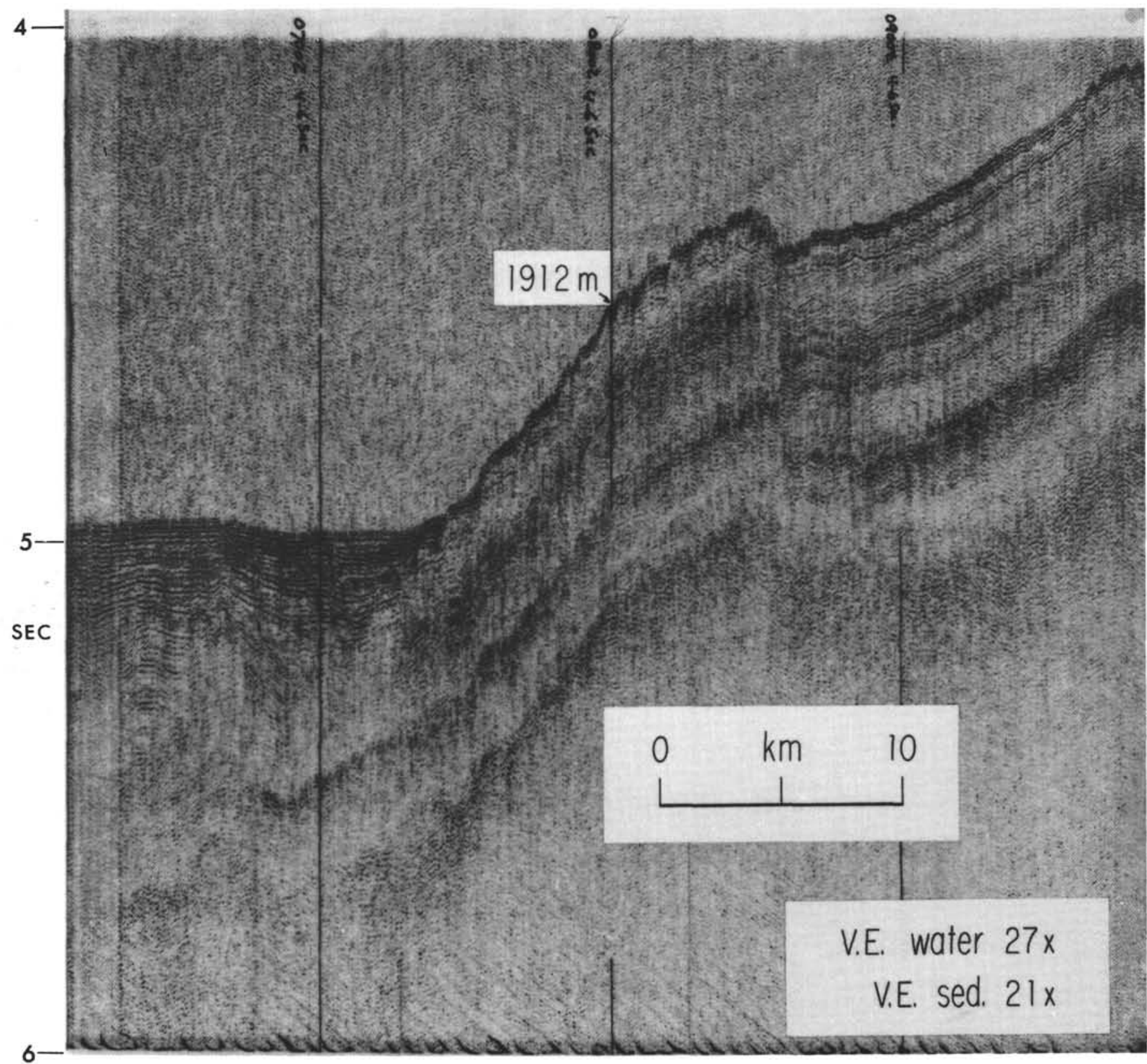

Figure 6. Photograph of CIRCE Leg III seismic reflection section at the west flank of the Ninetyeast Ridge at $6^{\circ} 31^{\prime} N$. Note prominent fault in pelagic section on Ninetyeast Ridge and tectonic disturbance of onlapping turbidites. 


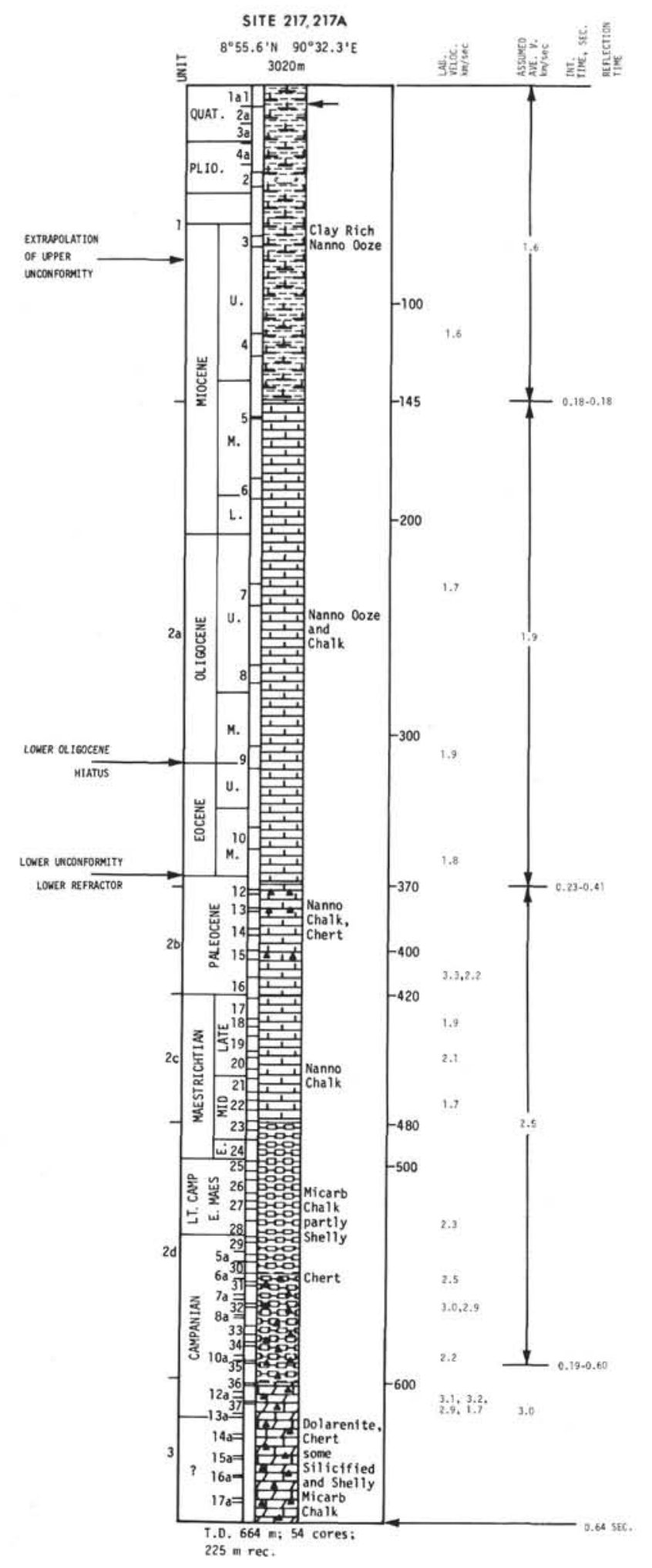

Figure 7. Stratigraphic log of Holes 217, 217A (Site Report, Chapter 8) with unpublished velocity measurements (A. C. Pimm, personal communication) and correlations with seismic work in the Bay of Bengal.

uplift or deformation. Various possibilities can be suggested, such as diapirism, deep-seated volcanic activity, mid-plate compression, etc., but we have no basis for

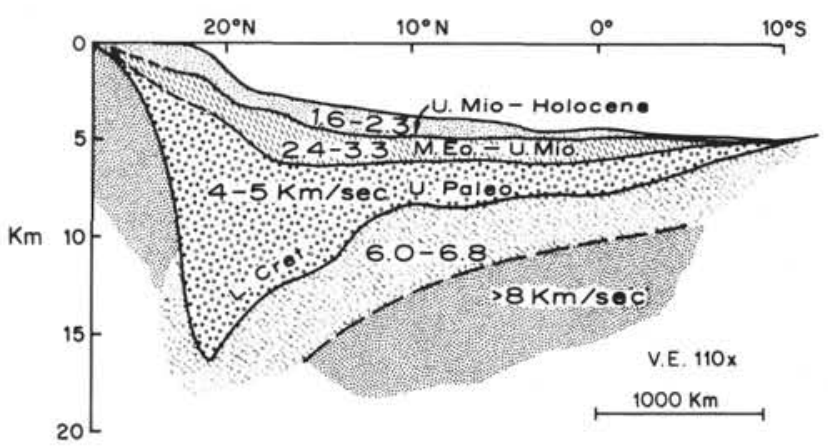

Figure 8. Longitudinal seismic-stratigraphic section from the Bengal Basin on land down the line of profile (Figure 2) to $10^{\circ} \mathrm{S}$.

choosing. Eittreim and Ewing (1972) suggest that hills located at $7^{\circ} \mathrm{S}$ and $80^{\circ} \mathrm{E}$ lie in and are related to the seismic zone first recognized by Stover (1966) and suggested by Sykes (1970) to be a nascent subduction zone. Our observations in this region show, however, that such hills are not concentrated in this zone, but in fact are distributed along a broad basement swell roughly paralelling the Ceylon (Sri Lanka)-Indian coasts between $82^{\circ}$ and $87^{\circ} \mathrm{E}$ and about $1^{\circ}$ and $12^{\circ} \mathrm{N}$.

The fact that the unconformities also appear to coincide with refraction horizons and velocity changes implies a change in lithology or in consolidation, or both. These could occur either with changes in relative proportions of turbidites versus pelagics, due to a change in circulation, or more probably a change in terrigenous sediment input from the source areas, or a hiatus, or period of very slow deposition long enough to permit more complete consolidation. An unconformity in the turbidites of the fan will not necessarily pass into an unconformity in the pelagics over the hills of the Ninetyeast Ridge, because the controlling factors are different. Our lower unconformity appears to coincide with a reflector in the pelagics on the Ninetyeast Ridge, while our upper unconformity does not.

Finally, the pulses in turbidity current activity reported at Site 218 may be explained by several different possible causes. They may be related to channel migrations such as occur commonly in this and other fans (Curray et al., 1971), leaving large areas of the fan without sources of terrigenous supply. The youngest may be caused by Quaternary changes of sea level which put the Swatch of No Ground submarine canyon alternately in and out of reach of supply from the delta and shoreline, or they may be caused by tectonics in the source area and increases or decreases in amount of supply of terrigenous sediment. These would imply plate-edge tectonic changes which might or might not be reflected in coeval mid-plate tectonic events.

Faulting is apparent on most reflection profiles crossing the Ninetyeast Ridge (Figures 5 and 6). In the vicinity of Site 217 the faulting appears to be post-late Paleocene (lower unconformity), based on equal thickness of section below that horizon, both on the relatively upthrown and downthrown blocks, whereas the section younger than that horizon is thicker over the relatively downthrown block. On the flanks of the Ninetyeast Ridge, onlapping turbidites 
are deformed largely in the section older than uppermost Miocene or pre-upper unconformity. Thus, the recorded tectonically controlled structure on and adjacent to the Ninetyeast Ridge appears to be largely post-late Eocene and pre-uppermost Miocene in age. As such, it postdates the period of major subsidence of the Ninetyeast Ridge from shallow to relatively deep water.

\section{SUMMARY AND CONCLUSIONS}

1) The lower facies, below 600 meters at Site 217 and the similar oldest sediments at Sites 214 and 216 are shallow-water facies, older at the north end of the Ninetyeast Ridge and younger toward the south. They were deposited at the time these Ninetyeast Ridge hills were islands. We suggest that the islands were built to sea level as the plate passed over a mantle plume. The northeastsouthwest trends of the hills were determined by direction of the initial rifting of India away from Antarctica in a northwest-southeast direction.

2) The overlying sediments, 370 to 600 meters in Site 217 and the equivalents in Sites 214 and 216 , represent the major period of subsidence after passage over the plume.

3) Our lower unconformity and refracting horizon, traced to about 370 meters in 217 , Paleocene to middle Eocene in age, happens also to correlate with a lithologic change in 217 and a reflector in the pelagic sediment on Ninetyeast Ridge. We interpret this as the time of first collision of "greater," or Gondwanaland, India with the subduction zone lying off the southern margin of Asia. The older underlying sediments of the Bay of Bengal represent deposits of a mid-plate continental margin continental rise. They are the great bulk of the sediments in the bay, as shown in Figure 8. These older sediments are of high velocities, 4 to $5 \mathrm{~km} / \mathrm{sec}$, and could well be consolidated shales or sandstones, lithified pelagic carbonates, and probably contain some volcanics and perhaps some evaporites in the older sections. The thinner part of the section south of the equator (Figure 8) could be normal oceanic layer 2 of predominantly volcanics, but the thicker section lying near the Indian continental margin must be predominantly sediments. It may be of significance or coincidence that this time, about 53 m.y., is the time of initiation of separation of Australia and Antarctica. This rifting may be related to the collision of continental India with a subduction zone.

4) The lower Oligocene hiatus in 217 and the hiatus in the Oligocene in most other sites of this leg and other DSDP legs in the southwestern Pacific and Indian oceans must be related to major changes in oceanic circulation caused by the widening seaway between Australia and Antarctica. It is probably coincidence that this is approximately the time of establishment of present direction and speed of plate motion in the northeastern Indian Ocean.

5) Middle Miocene was the time of the lithologic change at 145 meters at Site 217 and pulse 4 turbidity current activity near the bottom of Site 218. At this time, a lithologic change in the pelagic sediments in the form of an increase in the clay content marks a possible increase in turbidity current activity on the adjacent Bengal Fan. No apparent mid-plate tectonic activity has been observed in the form of uplift or unconformity, however, so this may be a plate motion change affecting only the plate edge. This is the time of major uplift of the modern Himalayas proposed by Gansser (1964). It is also approximately the time of change in the sub-Himalayas from Muree deposition derived from the south to Siwaliks derived from the north from the uplifting mountains. Thrusting and uplift were also occurring in the Andaman and Nicobar islands.

6) Turbidity current pulse 3 at about 575 meters in 218 , early in late Miocene time, could also be the time of Gansser's (1964) uplift of the Himalayas (plate-edge tectonics), but here again no obvious mid-plate tectonic events such as uplift of hills or unconformity have been observed in the Bay of Bengal. This is the time of start of a change in heavy minerals in the fan sediments (Thompson, Chapter 38) from more low-rank metamorphic-source rocks to more acid igneous and high-rank metamorphics, perhaps relfecting orogeny, uplift, and deeper erosion in the Himalayas. The other possible cause for the change in heavy minerals and turbidity current activity could be a major and long-lasting shift of a principal distributary in the fan valley system on the Bengal Fan. The former explanation appears more probable.

7) Our upper unconformity and upper refractor correlate with the start of turbidity current pulse 2 , the base of the silt and sand unit in 218, in uppermost Miocene time. This pulse, which culminates in Pliocene time, also apparently correlates with the turbidites in Site 211 on the distal part of the Nicobar Fan and with a major change in heavy minerals in Site 218. This must be a time of both plate-edge and mid-plate tectonic activity. Further uplift in the Himalayas increased the erosion rates and changed the source rocks, resulting in lithologic changes in the fan. At the same time, hills in the Bay of Bengal started uplifting, and a slow rate of deposition prior to onset of turbidity current activity lasted long enough to permit consolidation at the sea floor and increase in sediment velocity.

8) Turbidity current pulse 1 in late Pleistocene time marks a change in depositional conditions which must have been due to Pleistocene fluctuations in sea level. During periods of Pleistocene low stands of sea level, more of the sediment from the confluent Ganges and Brahmaputra rivers poured into the Swatch of No Ground submarine canyon and passed on down to the Bengal Fan. This would, in turn, have caused rapid channel migration to further complicate the sedimentary record. During high stands, as today in the Holocene, most sediment is trapped in the rapidly subsiding delta and on the inner shelf, and relatively little sediment is transported to the fan.

\section{ACKNOWLEDGMENTS}

This work was done with support of the Office of Naval Research. We have benefitted greatly during preparation of this manuscript from discussions with A. C. Pimm, R.W. Thompson, and R. L. Fisher.

\section{REFERENCES}

Brunnschweiler, R. O., 1966. On the geology of the Indoburman Ranges: J. Geol. Soc. Australia, v. 13, p. 137. 
Carey, S. W., 1958. A tectonic approach to continental drift. In Continental drift: A symposium: Carey, S. W. (Convenor). Hobart (University of Tasmania).

Curray, J. R., Emmel, F. J., Moore, D. G., and Normark, W. R., 1971. Migrating Mega-channels and sediment distribution. Bengal Deep-Sea Fan (abstract): Int. Sediment. Congr., VIII Int. Assoc. Sedimentologists, v. 19.

Curray, J. R. and Moore, D. G., 1971. Growth of the Bengal Deep Sea Fan and denudation in the Himalayas: Geol. Soc. Am. Bull., v. 82, p. 563.

Curray, J. R., Moore, D. G., Raitt, R. W., and Emmel, F. J., in press. The Bengal Geosyncline, from rift to orogeny: Geology.

Du Toit, A. L., 1973. Our wandering continents: Edinburgh and London (Oliver and Boyd).

Eittreim, S. L. and Ewing, J., 1972. Mid-plate tectonics in the Indian Ocean: J. Geophys. Res., 77, p. 6413.

Gansser, A., 1964. Geology of the Himalayas: London (Interscience).

, 1966. The Indian Ocean and the Himalayas, a geological interpretation: Eclog. Geol. Helv., v. 59, p. 831.

Gaskell, T. F., Hill, M. N., and Swallow, J. C., 1959. Seismic measurements made by H.M.S. Challenger in the Atlantic, Pacific and Indian Oceans and in the Mediterranean Sea: Trans. Roy. Soc. London, Ser. A, v. 251, p. 23.

Heezen, B. C. and Tharp, M., 1965. Physiographic diagram of the Indian Ocean, the Red Sea, the South China Sea, the Sulu Sea, and the Celebes Sea: Geol. Soc. Am., Scale $1: 11,000,000$.
Karunakaran, C., Ray, K. K., and Saha, S. S., 1964. A new probe into the tectonic history of the Andaman and Nicobar Islands: Rock Deformation and Tectonics. Int. Geol. Congr., 22nd, Part IV, India, 1964.

McKenzie, D. P. and Sclater, J. G., 1971. The evolution of the Indian Ocean since the late Cretaceous: Geophys. J. Roy. Astro. Soc., v. 25, p. 437.

Moore, D. G., Curray, J. R., and Raitt, R. W., 1971. Structure and history of the Bengal Deep-Sea Fan and Geosyncline, Indian Ocean (abstract): Int. Sediment. Congr., Int. Assoc. Sedimentologists, v. 69.

Rodolfo, K. S., 1969. Bathymetry and marine geology of Andaman Basin and tectonic implications for southeast Asia: Geol. Soc. Am. Bull., v. 80, p. 1203.

Sclater, J. G. and Fisher, R. L., in press. The evolution of the east central Indian Ocean with emphasis on the tectonic setting of the Ninetyeast Ridge: Geol. Soc. Am. Bull.

Sengupta, S., 1966. Geological and geophysical studies in western part of Bengal Basin, India: Am. Assoc. Petrol. Geol. Bull., v. 50, p. 1001.

Smith, A. G. and Hallam, A., 1970. The fit of the southern continents: Nature, v. 225 , p. 139.

Stover, C. W., 1966. Seismicity of the Indian Ocean: J. Geophys. Res., v. 71 , p. 2575.

Sykes, L. R., 1970. Seismicity of the Indian Ocean and a possible nascent island arc between Ceylon and Australia: J. Geophys. Res., v. 75, p. 5041.

Veevers, J. J., Jones, J. G., and Talent, J. A., 1971. Indo-Australian stratigraphy and the configuration and diapersal of Gondwanaland: Nature, v. 229, p. 383. 